\title{
Tutela Provisória no Processo Coletivo: Um Diálogo Entre o Novo Código de Processo e a Lei da Ação Civil Pública*
}

\author{
Elaine Harzheim Macedo**
}

1. Introdução: cidadania plural versus tempo no processo. 2. Conflito coletivo e processo coletivo: variações. 3. Mora processual e o esforço de sua superação. 4. Jurisdição definitiva e jurisdição provisória. 5. Momentos processuais das tutelas de urgência. 5.1. A antecipação incidental. 5.2 A antecipação em caráter antecedente. 5.3 A extinção do processo por opção do réu na tutela antecipada requerida em caráter antecedente: princípio da utilidade do processo. 5.4. A tutela cautelar antecedente e a tutela cautelar incidente. 6. Estabilização da tutela provisória antecedente. 7. Tutela de urgência e processo coletivo: diálogo das fontes. 8. Considerações finais. Referências.

\section{RESUMO}

O processo coletivo é um espaço democrático de composição de conflitos que deve guardar aderência a tutelas distintas voltadas a uma cidadania plural ou coletiva, titular de interesses ou direitos difusos ou de direitos restritos a um determinado grupo. A exemplo do processo individual, também o tempo e a mora processual podem ser responsáveis pela inefetividade da prestação jurisdicional devida no processo coletivo, justificando que o regime da tutela provisória, contemplado no Código de Processo Civil de 2015, seja aplicado, no que couber, à demanda coletiva, dialogando com a Lei da Ação Civil Pública, atual matriz processual do processo coletivo brasileiro. Tanto a tutela antecipada incidental como a tutela cautelar, antecedente ou incidental, guardam aderência ao processo da Lei n. 7.347/85, porém isso não acontece com a figura da tutela antecipada requerida em caráter antecedente, considerando os bens da vida tutelados na ação coletiva, que reclamam um pronunciamento definitivo. Também a previsão da responsabilidade objetiva no âmbito da tutela provisória, com a reparação dos prejuízos causados ao réu, é impertinente ao processo coletivo, devendo ser reservada sua incidência tão somente

* Revisão de português do presente artigo realizada pelo Departamento de Língua Portuguesa da UNICHRISTUS.

** Doutora e Mestre em Direito, Especialista em direito processual civil, Professora na Graduação e no Programa de Pós-Graduação em Direito junto à PUCRS. Desembargadora aposentada do Tribunal de Justiça do Rio Grande do Sul. Ex-Presidente do Tribunal Regional Eleitoral do Rio Grande do Sul. Membro do Instituto dos Advogados do Rio Grande do Sul e da Associação Brasileira de Direito Processual Constitucional. Presidente do IGADE - Instituto Gaúcho de Direito Eleitoral. Advogada. E-mail: elaine@fhm.adv.br 
nas hipóteses de responsabilidade subjetiva, se reconhecida a má-fé no agir do ente coletivo.

Palavras-chave: Processo coletivo. Tutela provisória. Lei da Ação Civil Pública. Novo CPC.

\section{INTRODUÇÃO: CIDADANIA PLURAL VERSUS TEMPO NO PROCESSO}

O Direito está em crise. O próprio Estado de Direito está em crise. Os movimentos de releituras, de reconstrução, de desvelamento de institutos atingem as nações e os ordenamentos jurídicos do planeta, praticamente podendo se afirmar que não há espaço que não esteja sendo objeto de debate, não só no âmbito jurídico, como na própria organização política e da sociedade como um todo.

O processo não está imune a essa crise. É nesse universo maior que se propõe a (re)discutir alguns institutos processuais, pois o processo, como produto cultural, está a exigir uma reordenação do pensamento jurídico.

Essa discussão pode tanto afetar o processo enquanto procedimento ou rito (estudo de suas fases); o processo enquanto agir de todos aqueles que nele intervêm (poderes, deveres e responsabilidades), como verdadeiros agentes - e não meros sujeitos, como a doutrina tradicional sempre tratou as partes, o juiz e quaisquer outros intervenientes da relação processual; o processo enquanto função da jurisdição e de seu produto maior, a prestação jurisdicional responsável pela composição do conflito (sentença e suas eficácias); e outros tantos vieses que o processo autoriza.

Neste trabalho, pretende-se abordar duas dessas importantes movimentações e o respectivo ponto de encontro: a) o processo coletivo, como espaço jurídico de construção do direito concreto ou, quiçá, como espaço capaz de tutelar a própria ordem jurídica, faceta que, tradicionalmente tem se reconhecido, ínsita o processo objetivo, mas que, em determinada dimensão, também, qualifica o processo coletivo, cuja principal marca se faz pela cidadania coletiva. A existência de sujeitos múltiplos nas variáveis fontes de coletivização de interesses ou direitos é determinante para a concepção do processo coletivo, o que inevitavelmente vai se refletir na prestação jurisdicional a que o Poder Judiciário está ungido; $b$ ) ao falar em prestação jurisdicional, o problema se transmuda para outro foco de preocupação, o tempo no processo. Se já no processo subjetivo individual o tempo é uma batalha a ser vencida, por certo no processo que tutela os interesses ou direitos de uma cidadania coletiva, a batalha quase se torna a guerra. Vencer a mora processual encontra no Código de Processo Civil de 2015 uma (re)discussão dos paradigmas das tutelas de urgência e da tutela cautelar, ofertando-se como (parte da) solução a construção sistêmica de uma prestação jurisdicional provisória como alternativa a uma prestação jurisdicional definitiva.

Ainda que a (parcial) resposta legislativa ao problema da mora processual tenha sido construída para o processo subjetivo individual, sua transmudação 
para o processo coletivo requer reflexão e crítica, tornando-se ponto de encontro a ser enfrentado neste trabalho.

\section{CONFLITO COLETIVO E PROCESSO COLETIVO: VARIAC̣ÕES}

Discussão da maior importância que se põe é o reconhecimento e a consequente distinção entre os diversos conflitos que envolvem a cidadania (individual ou coletiva), podendo-se classificar os conflitos, tendo por ângulo os sujeitos que integram tais conflitos e que carecem da intervenção do Poder Judiciário para ver tutelados os seus interesses, em três grandes grupos:

1. O conflito individual subjetivo, que já é do domínio - tanto quanto possível - da cultura jurídica, até porque as pessoas, desde sempre, relacionam-se entre si a partir dos mais diversos interesses, sobre eles controvertendo, a exigir a intervenção da ordem jurídica. Aqui, o Direito Processual goza de uma milenar tradição, irrelevante se o sistema jurídico adota orientação da common law ou da civil law.

2. O conflito coletivo, fenômeno que passou a afligir a sociedade a partir das novas ondas de direitos que a revolução industrial, a revolução do conhecimento, da ciência e da tecnologia passaram a produzir, levando os sistemas jurídicos à preocupação de incluir no rol de suas proteções e garantias os direitos coletivos, assim compreendidos como os direitos transindividuais e de natureza indivisível, podendo se caracterizar pela nota do difuso (pessoas indeterminadas e ligadas por circunstâncias de fato), estabelecendo uma relação metaindividual, ou pela característica de integrarem os respectivos titulares um grupo, ainda que indeterminado, ligados por circunstância de fato.

O conflito coletivo, nesse particular, aproxima as duas situações que subjetivamente se distinguem porque, no primeiro caso, a titularidade é absolutamente indeterminada, difusa, metaindividual, podendo estender-se inclusive no tempo, atingindo futuras gerações (caso do direito ambiental), enquanto que, no segundo, a titularidade define-se por um grupo determinado (classe, categoria, associação) havendo apenas uma relativa indeterminação quanto aos respectivos titulares.

3. O conflito repetitivo, muito afeito pela sociedade de consumo, que abrange fundamentalmente interesses ou direitos individuais homogêneos, assim os decorrentes de origem comum. Aqui, talvez, o maior dilema quando esse conflito é repassado para o processo. Primeiro, porque nem sempre o possível substituto processual a provocar a devida prestação jurisdicional é bem definido ou mesmo legitimado pelo ordenamento jurídico para atuar em juízo. No Brasil, por exemplo, discutiu-se muito se a Defensoria Pública, órgão público ligado ao Poder Executivo, estaria legitimada a promover ação civil pública em favor de um grupo de consumidores de determinado produto ou serviço, até que a legislação contemplou a hipótese. Por outro lado, tais tipos de conflitos ensejam, porque não há expressa vedação, a propositura de ações individuais, principal responsável pelo fenômeno da numerosidade do processo ${ }^{1}$. 
De um modo geral, possível concluir que há, na verdade, duas formas básicas de se enfrentar o processo enquanto um espaço democrático de construção do direito do caso concreto: a primeira, estudando os seus fundamentos, princípios, institutos, categorias e conceitos e aplicando essas doutrinas no direito material e nos conflitos de interesses; a segunda, invertendo-se os polos, partindo do estudo dos conflitos e da sua regulação no ordenamento de direito material, constitucional ou infraconstitucional, com efeito de buscar a solução mais adequada, efetiva, tempestiva para a sua composição. Por certo que da posição a ser adotada dependerá visceralmente o resultado a ser produzido² ${ }^{2}$.

Não é por outra razão que se toma mão da lição de um dos grandes pensadores da atualidade do processo civil brasileiro, traduzida na obra que veio a público poucos dias após sua morte, contrapondo os pensamentos de Jerome Frank e Dworkin

Para mim, que sempre fui advogado forense, é mais fácil aceitar o ponto de vista de um ilustre magistrado americano, um dos principais nomes do chamado realismo, quando ele assevera que a maioria dos pleitos são "pleitos sobre fatos"; e que, mesmo aqueles casos excepcionais, que compreendem também difíceis questões sobre a norma aplicável são também, em parte, "pleitos sobre fatos"; na incontável maioria dos pleitos, a predição das sentenças envolve, no todo ou em parte, uma profecia sobre as crenças dos juízes de primeira instância ou dos jurados, sobre os fatos. ${ }^{3}$

Nesse sentido, possível afirmar que os conflitos de interesses que justificam a existência do processo são conflitos que têm por fundamento os fatos da vida, do cotidiano, o que nem sempre é perceptível ou levado em consideração na concepção doutrinária que se dissemina no meio acadêmico, com evidentes reflexos na prática forense. Pela ótica vigente, os institutos processuais passam a ser estudados, dissecados, observados a partir de uma abstração conceitual, de sua natureza jurídica, sua classificação, efeitos, etc e, devidamente consolidados, passam então, tais elucubrações, a ser aplicadas aos fatos da vida, à relação de direito material, aos conflitos de interesses. É como se primeiro, nos laboratórios, inventassem-se os remédios, a partir de conhecimentos químicos e farmacológicos, para depois se buscar a que doença eles se destinam ou podem-se destinar.

Importante, nesse ponto, lembrar que o Direito - e disso o processo não se desgarra - é um produto da cultura, o que o torna fundamentalmente contingencial ${ }^{4}$, irrelevante, no ponto, se o conflito é individual, coletivo ou repetitivo, a exigir do operador e do jurista comprometimento com a consagração da ordem jurídica e a tutela dos direitos fundamentais, entre os quais, o acesso à justiça por meio do devido processo.

O Código de Processo Civil de 2015, Lei n. 13.105, embora substancialmente voltado para a composição do conflito subjetivo individual, traz uma forte contribuição para o enfrentamento dos conflitos repetitivos, introduzindo no sistema processual brasileiro o precedente com força vinculativa, o que, certamente, não é objeto deste trabalho, mas que não pode deixar de ser registrado pela importância 
que a inovação poderá representar na construção de novos paradigmas.

\section{MORA PROCESSUAL E O ESFORÇO DE SUA SUPERACุÃO}

A mora processual é inevitável. Seria utópico imaginar uma organização judiciária absolutamente isenta ao custo temporal que, por vezes, é inerente a outros valores tutelados no âmbito da jurisdição, como o acesso à justiça, o contraditório, a ampla defesa. Contudo, o sistema deve, tanto quanto possível, vacinar-se contra a mora processual, minimizando a seu - quase sempre - nefasto reflexo sobre a efetiva prestação jurisdicional.

Já no Código de 1973, o legislador pátrio esforçou-se para vencer a mora processual, construindo soluções processuais, como a contemplação do processo cautelar e os provimentos antecipatórios.

O Código de Processo Civil de 2015, Lei n. 13.105, inova também nesse particular, revisitando as tutelas de urgência e a tutela cautelar, a partir de uma nova concepção, que tem como foco a concretização da efetividade e a tempestividade da prestação jurisdicional, sob um vetor constitucional de processo democrático.

Um estatuto processual que se propõe a produzir um processo fortalecido pela efetividade e tempestividade da prestação jurisdicional, certamente, tem que dar uma atenção especial às tutelas que tenham em seu conteúdo um pronunciamento antecipado no tempo, seja de natureza satisfativa, seja de natureza cautelar, que, nas últimas décadas, a doutrina enfrentou como tutelas de urgência ou ainda tutelas diferenciadas, identificadas como tutelas antecipadas, tutelas inibitórias, tutelas cautelares, gerando inclusive reformas processuais no Código de $1973^{5}$, a ponto de partir-se, no passado, da absoluta distinção entre o que então se identificava como liminares e cautelares, para desaguar na aproximação das agora chamadas tutelas antecipatórias e tutelas cautelares, permitindo inclusive a adoção da fungibilidade entre as pretensões deduzidas o que foi consagrado pelo art. 273, § 7\%, do CPC de 1973.

Nesse aspecto, talvez um dos maiores cortes produzidos na Lei n. $13.105 / 2015$ tenha sido exatamente o tratamento dado a tais especiais formas de pronunciamentos judiciais, de modo a simplesmente revogar o Livro das Cautelares e instituir, no Livro V da Parte Geral, a Tutela Provisória, que passa a contar com a Tutela de Urgência e a Tutela da Evidência, como espécies e a Tutela Antecipada e a Tutela Cautelar como subespécies da Tutela de Urgência.

O texto em estudo logrou, de outra banda, contemplar uma tradição não só regulamentadora, mas doutrinária e jurisprudencial sobre o tema, dada sua relevância, inovando, porém, no seu tratamento, o que, de certa forma, é o ideal de um novo Código, agregando passado, presente e futuro sob uma nova perspectiva. Já por aí, somam-se motivos para que o intérprete se debruce sobre 
essa nova realidade, extraindo do texto sua máxima otimização, olhando o novo com olhos de novo.

Importante destacar, principalmente quando se está frente à renovação da legislação processual sobre o processo coletivo ${ }^{6}$, que tradicionalmente tem se utilizado ou da figura da antecipação de tutela ou da ação cautelar para atender casos de urgência em sede de ação civil pública (e por isso mesmo o presente debate), que o novo Código, ao revogar (ou não prever) o processo cautelar, não deixou de contemplar as respectivas pretensões, quando, em seu art. 301, cuidou de ajustá-las, senão todas, as que efetivamente guardam natureza acautelatória, à tutela provisória cautelar, nos seguintes termos:

Art. 301. A tutela de urgência de natureza cautelar pode ser efetivada mediante arresto, sequestro, arrolamento de bens, registro de protesto contra alienação de bem e qualquer outra medida idônea para asseguração do direito.

Por outro lado, no capítulo das provas, nos arts. 381/383, o Código introduz um incidente processual denominado Da Produção Antecipada de Prova, abrangendo não só a autêntica antecipação de prova, mas também a pretensão exibitória, conforme inciso III: "o prévio conhecimento dos fatos possa justificar ou evitar o ajuizamento de ação".

E no capítulo Dos deveres das Partes e seus Procuradores, o art. 77, inciso VI, estabelece: "não praticar inovação no estado de fato do bem ou direito litigioso", compondo, por outra via, hipótese típica da ação de atentado, até então regulada pelos arts. 879 a 881 do CPC de 1973.

Com tais providências, o estatuto, depurando o que considera tutela provisória em sentido estrito, culminou por concentrá-las em livro próprio, contrapondo-as à tutela definitiva, mas ambas enfrentando e decidindo o mérito (total ou parcial) do conflito, num espectro temporal distinto, com vistas à superação da mora processual.

\section{JURISDIÇÃO DEFINITIVA E JURISDIÇÃO PROVISÓRIA}

O paradigma do processo civil brasileiro sempre foi voltado à composição definitiva da lide, o que não sofreu alterações, em sua substância, no Código de 2015. São inúmeros os institutos processuais voltados a afirmar a segurança jurídica que deve conformar a atuação jurisdicional, tanto no sentido de limitá-la como de afirmá-la, cuja origem remonta às influências racionalistas ${ }^{7}$ que conduziram a modernidade. Instrumentos atrelados a essa ordem processual, o processo de conhecimento e o correspondente procedimento comum (ordinário, no CPC de 1973), a cumulação de ações, a modificação da competência por força da conexão ou da continência e consequente reunião de processos, o litisconsórcio facultativo, a amplitude probatória e, por certo, o que mais revela, o instituto da coisa julgada, que por sua importância no sistema constituído foi elevado à garantia constitucional. 
Uma das críticas que se faz ao paradigma da ordinariedade - umbilicalmente vinculado à segurança jurídica e à definitividade das decisões - é o divorciamento entre o processo e o mundo dos fatos, pela superação do interesse público (no sentido de "dizer o direito") sobre as contingências do conflito individual. Piero Calamandrei distinguia duas concepções de jurisdição, uma subjetiva e outra objetiva, reconhecendo a ambas uma certa parcela de razão, mas entendendo que o caráter político e histórico seria determinante para a manutenção de uma ou outra tendência, destacando, após definir a concepção subjetiva como um serviço posto a favor dos litigantes, a sobreposição da concepção objetiva:

Viceversa, cuando se parte de la concepción autoritaria, que ve en el derecho, ante todo, la voluntad del Estado y en la observancia del derecho, el respeto a la autoridad, resulta que también en la definición de la finalidad de la jurisdicción queda en la sombra del interés individual de la defensa del derecho subjetivo, y surge en primer plano el interés público en la observancia del derecho objetivo: no hay necesidad de explicar la razón de que, hoy, esta segunda concepción de la jurisdicción civil aparezca históricamente más en armonía con el derecho positivo vigente ${ }^{8}$

Essa cultura processual foi recepcionada pela doutrina brasileira à exaustão, principalmente sob a ótica do Código de 1973. Porém, paralelamente, a radicalidade do processo de conhecimento e seu padrão procedimental provocaram uma reação: ao mesmo tempo em que se encastelou nas legislações processuais, até porque atende os interesses de determinados grupos econômicos e políticos, teve que ceder espaço, especialmente a partir da segunda metade do século XX quando a sociedade como um todo reformulou-se, as técnicas de sumarização, muito tendo contribuído para tanto o processo de constitucionalização dos Estados no período pós guerra, revigorando a legislação infraconstitucional pelos valores, princípios e garantias constitucionais.

Não é outra a lição de Jânia Maria Lopes Saldanha

Arremedos de sumarização, na tentativa de ocupar espaços adredemente reservados ao procedimento ordinário, apareceram. Daí foi um passo para a busca da proteção de direitos pela via da cautelarização e da antecipação por meio de medidas antecipatórias de caráter provisório, que são as formas de tutela de urgência em vigor na maioria dos sistemas de tradição civil ${ }^{9}$.

Põem-se em polos distintos e opostos a definitividade e a provisoriedade, ambas abarcadas pelo processo, cumprindo a lei, até porque não abandonamos o princípio da legalidade, conforme art. $5^{\circ}$, inciso II, da CR, mas especialmente ao intérprete a escolha de Sofia ${ }^{10}$, para, obedecida a conformação possível e os limites do processo judicial democrático e participativo, a prestação jurisdicional ganhar aderência ao conflito de interesses que nasce da vida e de suas complexidades e do direito material, responsável pela regulação das relações e situações jurídicas. 
Mas não há como escapar da encruzilhada: ou o conflito será tratado pela opção da ordinariedade (agregando, aqui, os institutos voltados a preservar a segurança jurídica e a definitividade da prestação jurisdicional) ou será submetido à jurisdição provisória, caracterizada fundamentalmente por técnicas que resguardam a mais ampla efetividade (pronunciamentos de carga executiva ou mandamental), corte de conhecimento (cognição sumária) e encurtamento procedimental (tempestividade da prestação jurisdicional).

A técnica da sumariedade tanto pode se dar numa fase inicial do processo instaurado, remetendo para outra subsequente a ordinariedade, ou ainda se se esgotar isoladamente num procedimento não exauriente. Tais procedimentos são dotados de forte carga decisional e significativa redução de julgamento.

De certa forma, tanto as tutelas definitivas como as tutelas provisórias estão comprometidas com a substancialização do processo, embora a prestação jurisdicional oriunda de processo de conhecimento plenário esteja muito mais sujeita aos riscos do divorciamento do direito material e, mais precisamente, dos fatos que ensejaram o conflito, contaminando-se pela abstração e pela virtualização do pronunciamento judicial, tema, porém, que foge ao conteúdo em exame. Diferentemente, as tutelas provisórias só se sustentarão no sistema processual se permanecerem aderentes à tutela do direito material e aos fatos subjudice, pois, se abduzidas pela generalização do processo ordinário, deixam de ser interditais para se transformarem em julgamento e, o que é pior, no mais das vezes, nulo por ofensa a todos as regras ínsitas ao devido processo: contraditório, ampla defesa, coisa julgada.

O Código de 2015 comprometeu-se com a construção e solidificação da jurisdição provisória, dando-lhe corpo próprio, em livro incluído na parte geral. Essa técnica legislativa permite que a tutela provisória seja adotada em qualquer processo ou procedimento e, igualmente, a qualquer grau de jurisdição.

De registrar que o conceito de provisoriedade não cumpre à lei processual estabelecer. É da doutrina que se podem extrair as fontes de conhecimento para melhor compreender o seu conteúdo e, por derradeiro, pela intervenção judicial no enfrentamento dos conflitos, quando tais proposições serão postas à prática, com a construção da jurisprudência.

O art. 294 do Código de 2015 limita-se a dizer que "a tutela provisória pode fundamentar-se em urgência ou evidência”, dispondo seu parágrafo único que "a tutela provisória de urgência, cautelar ou antecipada, pode ser concedida em caráter antecedente ou incidental".

Superando discussão infértil do passado em relação às distinções entre cautelares e provimentos antecipatórios, o Código conciliou as duas espécies (ou subespécies) como integrantes da espécie mais geral das tutelas de urgência. Isso porque o Código introduziu a tutela da evidência, compondo, essa, com as tutelas de urgência, o gênero tutelas provisórias. 
Contudo, para aprofundar o conceito de provisoriedade, indispensável esclarecer o conceito de decisão. Ovídio A. Baptista da Silva, no ponto, sempre destacou, contrariando a doutrina até então prevalente, que o conceito de decisão tanto poderia estar atrelado ao julgamento (em princípio, aderente à definitividade) como aos pronunciamentos de natureza provisória, justificando a existência de sentenças liminares, a saber

Ao contrário dessa doutrina, entendemos que pode haver decisões provisórias sobre a lide, tomadas com base num juízo de verossimilhança sobre a existência do direito, as quais, sendo provisórias, não vinculam o juiz da sentença final, podendo ser por este revogadas livremente ${ }^{11}$.

Este, talvez, seja o ponto mais importante para distinguir provisoriedade de definitividade: nas decisões provisórias o juiz, independentemente da intervenção de órgão jurisdicional recursal, pode, a qualquer tempo antes da sentença, modificar a sua decisão, pautada, até então, na sumariedade dos juízos fundados na verossimilhança.

Esse traço definidor se fazia presente tanto nas ações cautelares promovidas à luz do Livro III do Código de Processo Civil de 1973, como nas providências antecipatórias, como as previstas nos seus arts. 273, 461, § 3o ou 461-A, § 3०, como nos casos dos procedimentos especiais, a exemplo da liminar em sede de ação possessória, art. 928 do referido estatuto processual. As decisões proferidas em caráter de urgência, compreendidas como antecipatórias ou acautelatórias, emanavam da concretude do conflito de direito material, produzindo um pronunciamento judicial imediato, mas sem força de julgamento, carregado de força ou energia decisória, capaz de modificar o mundo fenomênico, sem prejuízo de sua provisoriedade, atreladas que estavam a um julgamento definitivo, este, sim, de significativo conteúdo de acertamento da relação ou situação jurídica conflituosa e por isso mesmo sujeito à definitividade, momento em que o juiz poderia concluir ou pela confirmação da decisão preliminar ou por sua desconstituição, por força da improcedência do pedido.

Para as hipóteses de medidas cautelares, o espaço jurídico para rever a decisão, pelo mesmo grau de jurisdição que concedeu a asseguração, seria ou o próprio processo cautelar (liminar $x$ sentença), ou, ainda, o processo principal quando do julgamento final e definitivo. Como resultado, a sentença que resolvia o processo cautelar não se resguardava da coisa julgada material.

Para os casos de provimentos antecipatórios, a sentença a ser prolatada ao final do processo seria o momento derradeiro para o juiz revisitar a decisão provisória. O comando provisório, portanto, contava expressa previsão temporal de validade e o que mais revela de vigência. Mas, ainda assim, comando de concretização, de efetividade, de realização do direito submetido à apreciação judicial.

O Código de 2015 optou por destacar o caráter da provisoriedade para construir uma jurisdição diferenciada, divorciada da jurisdição afeita ao processo 
de conhecimento, seja pelo rito do procedimento comum, seja pelos procedimentos especiais, e à definitividade das decisões judiciais. Com tal opção, desviou o foco das tutelas satisfativas e cautelares, que deu tanta margem à discussão no modelo de 1973 e nas reformas subsequentes, para as tutelas provisórias, distinguindo em seu âmbito aquelas que seriam de urgência e as que se qualificariam pela evidência.

A proposta, no mínimo, mostra-se conciliadora, tentando compor inúmeras teorias e correntes que se instauraram no processo civil brasileiro, nem sempre contribuindo para a eficiência da atuação do Poder Judiciário.

Ao fazer essa opção, por certo está o Código renunciando, por absoluta incoerência e incompatibilidade lógica, aos rigores do processo de conhecimento e da prestação jurisdicional definitiva quando da concessão da tutela provisória, com soluções próprias, como a do art. 297 e seu parágrafo único:

Art. 297. O juiz poderá determinar as medidas que considerar adequadas para a efetivação da tutela provisória.

Parágrafo único. A efetivação da tutela provisória observará as normas referentes ao cumprimento provisório da sentença no que couber.

Somando-se a essas disposições - de forte executividade da prestação jurisdicional provisória -, agrega-se o art. 139, que trata dos poderes do juiz na condução processual, mais precisamente em seu inciso IV:

Art. 139. O juiz dirigirá o processo conforme as disposições deste Código, incumbindo-lhe:

\section{(...)}

IV - determinar todas as medidas indutivas, coercitivas, mandamentais o sub-rogatórias necessárias para assegurar o cumprimento de ordem judicial, inclusive nas ações que tenham por objeto prestação pecuniária.

Entre a jurisdição da provisoriedade e a jurisdição da definitividade (essa última objeto de sentença e sujeita ao instituto da coisa julgada), ambas indispensáveis à função do Poder Judiciário enquanto responsável pela administração da justiça do caso concreto, há um elo de intercomunicação que permite que o provisório se torne definitivo. Mas há, também, a hipótese de que o provisório se esgote em si mesmo, sem que perca os efeitos produzidos sobre a relação de direito material, senão em todos, pelos menos em alguns casos precisos, que precisam ser cirurgicamente tratados, sob pena de esvaziamento da proposta e, o que é mais grave, ofensa ao devido processo legal.

\section{MOMENTOS PROCESSUAIS DAS TUTELAS DE URGÊNCIA}

O parágrafo único do art. 294 dispõe expressamente que a tutela provisória de urgência, cautelar ou antecipada, pode ser concedida em caráter antecedente ou incidental. Inova, no ponto, o Código de 2015 criando a figura da tutela antecipada requerida em caráter antecedente, que vem regulada nos arts. 303 e 304. 
Em apertada síntese, pode afirmar-se que:

- a tutela antecipatória pode ser concedida antes do processo definitivo ou em seu curso;

- a tutela cautelar pode ser concedida antes do processo definitivo (ou principal) ou em seu curso.

Há, portanto, uma aproximação das duas tutelas (antecipatória satisfativa e cautelar) no que tange ao tempo no processo.

\subsection{A antecipação incidental}

Tradicionalmente, sob a égide do Código de 1973 e das leis extravagantes que cuidam de tutelas antecipatórias, como é o caso da Lei dos Alimentos e da Lei do Mandado de Segurança, a tutela antecipatória era prevista exclusivamente na forma incidental ao processo em curso, podendo ser requerida e concedida liminarmente ou ainda no curso do processo. A ação cautelar, por sua vez, responsável pela concessão de medida cautelar, podia ser promovida de forma antecedente ou incidental ao processo principal, mas dele sempre dependente, conforme arts. 796, 801, inciso III, e 806, todos do Código de 1973:

Art. 796. O procedimento cautelar pode ser instaurado antes ou no curso do processo principal e deste é sempre dependente.

Art. 801. O requerente pleiteará a medida cautelar em petição escrita, que indicará:

(...)

III - a lide e seu fundamento.

Art. 806. Cabe à parte propor a ação, no prazo de 30 (trinta) dias, contados da data da efetivação da medida cautelar, quando esta for concedida em procedimento preparatório.

Esse sistema de concessão de tutelas de urgência no tempo foi alterado pelo Código de 2015, relativamente às tutelas antecipatórias, que se definem pela natureza satisfativa da pretensão deduzida, permitindo, a exemplo do que ocorre e continuará ocorrendo com a tutela cautelar, que, em determinadas situações, a tutela antecipatória seja requerida e concedida em caráter antecedente, como adiante se verá.

Quanto à tutela antecipatória incidental, embora o novo estatuto dela não cuide em título específico - apenas regulando expressamente a tutela requerida e concedida em caráter antecedente -, não há qualquer dúvida sobre sua previsão, que decorre tanto do parágrafo único do art. 294 como das disposições gerais estabelecidas no art. 300, a saber:

Art. 300. A tutela de urgência será concedida quando houver elementos que evidenciem a probabilidade do direito e o perigo de dano ou o risco ao resultado útil do processo. 


\section{(...)}

$\S 2^{\circ}$. A tutela de urgência pode ser concedida liminarmente ou após justificação prévia.

$\S 3^{\circ}$. A tutela de urgência de natureza antecipada não será concedida quando houver perigo de irreversibilidade dos efeitos da decisão.

Importante registrar que essa previsão - a exemplo da tutela antecipada requerida em caráter antecedente e da tutela cautelar - se aplica a qualquer procedimento, comum ou especial, a qualquer processo ou qualquer grau de jurisdição, desde que a regra especial não conte com previsão expressa para prover as tutelas de urgência ${ }^{12}$.

Nesse fio, se o processo foi instaurado como demanda contenciosa, estando a petição inicial preenchida com todos os requisitos, cumprirá ao juiz, ao recebê-la, apreciar o pedido de provimento antecipatório e decidir desde logo sobre seu (in)deferimento, citando-se o réu para audiência de conciliação ou mediação, se for o caso, aqui aplicando-se a regra do art. 334 do CPC/2015

No caso de deferimento do provimento satisfativo antecipatório, o réu ao ser citado e tomar conhecimento da decisão provisória, ou se conforma ou interpõe o agravo de instrumento (art. 1.015, inciso I). Tendo sido a decisão do juiz desfavorável ao autor, cumprirá a este, se assim entender, interpor o recurso antes referido. Mas tais desdobramentos não impedem que o processo tenha o seu curso normal, seja com a realização de audiência de conciliação ou de mediação, quando cabível, seja com a abertura do prazo de contestação.

O mais relevante é ter presente que o processo instaurado está apto, em tese, para, ao final, concluir por uma sentença de mérito que se revestirá pela definitividade, podendo essa sentença confirmar ou reformar a decisão provisória proferida liminarmente ou ainda no curso do processo (art. 294, parágrafo único, combinado com art. 300). De sorte que provisória é a decisão que (in)defere o pleito antecipatório, liberando o próprio juízo de alterá-la no todo ou em parte no curso do processo ou, especialmente, quando proferida a sentença definitiva. Nesse sentido, o disposto no art. 296: a tutela provisória conserva sua eficácia na pendência do processo, mas pode, a qualquer tempo, ser revogada ou modificada.

O que se revestirá, portanto, de estabilidade e imutabilidade, é a decisão de mérito proferida após o trâmite regular do processo, e não a decisão antecipatória.

A aplicação de tal procedimento e pretensão antecipatória no processo coletivo será objeto específico de enfrentamento em item próprio.

Mas o Código, como já registrado, inova, criando a figura da tutela de urgência antecipada requerida em caráter antecedente.

Trata-se, portanto, de decisão judicial provisória prevista para um momento anterior ao processo definitivo, ainda que dele não se afaste. 


\subsection{A antecipação em caráter antecedente}

No ponto, o Código de 2015 inova, cria a figura de uma tutela de urgência satisfativa antecedente, ou seja, que antecede à própria instauração do processo definitivo, o que até então, segundo tradição processual (Código de 1973), apenas no processo cautelar era previsto, criando um vínculo de dependência daquela (medida cautelar concedida de forma antecedente) a este (processo principal), com repercussões processuais importantes, como competência, postulação, decisão judicial, recurso.

A tutela antecipada de que cuida este capítulo está regulada pelos arts. 303 e 304. No art. 303, estão previstos o seu cabimento e a sua conversão em processo definitivo. No art. 304, o Código trata de uma (nova) figura, qual seja a estabilidade da decisão provisória e o agir do réu. Adianta-se, estabilidade da decisão provisória não se confunde com a estabilidade e imutabilidade da decisão definitiva o que será adiante melhor explorado.

Indo por partes. A tutela (de caráter urgente e satisfativo) antecedente pode ser requerida sempre que a urgência for contemporânea à propositura da ação, mas ainda não está o autor suficientemente preparado para desencadear a demanda com todos os seus requisitos indispensáveis, pois lhe faltam elementos tanto postulatórios como probatórios para perfectibilizar uma petição inicial apta a exigir um custo temporal que não pode ser suportado pelo autor, daí porque o caráter de urgência. Uma espécie de urgência urgentíssima.

A urgência deve ser exposta e fundamentada e estar atrelada ao perigo de dano ou do risco ao resultado útil do processo. Cláusula em aberto, que só a concretude do caso poderá definir.

Para tais hipóteses, o Código autoriza que o autor, provocando o Judiciário, se limite a expor os fundamentos necessários para descrição do quadro geral, com indicação do pedido (leia-se, definitivo) e exposição da lide, requerendo, base na urgência, a tutela antecipada, esta sim, especificada até porque gerará, em caso de deferimento, na forma do art. 297, comandos compulsórios e adjudicatórios, execuções, ordens, com interferência direta no mundo fenomênico.

Concedida a antecipação, oportuniza-se ao autor a emenda da inicial, no prazo de 15 (quinze) dias ou em outro prazo mais dilatado, se assim o juiz fixar, frente às peculiaridades do caso concreto, sob pena de extinção do processo sem resolução do mérito (e consequente cassação da medida concedida).

Atendida adequadamente a emenda, o réu será citado e intimado para a audiência de conciliação ou mediação que, se exitosa, ensejará a composição do conflito. Caso contrário, fluirá da audiência de conciliação ou mediação o prazo para contestar, conforme dispõe o art. 335 do CPC de 2015:

$O$ réu poderá oferecer contestação, por petição, no prazo de 15 (quinze) dias, cujo termo inicial será a data: I - da audiência de conciliação ou de mediação, ou da última sessão de conciliação, 
quando qualquer parte não comparecer ou, comparecendo, não houver autocomposição.

Entendendo o juiz que não há elementos para concessão da medida antecipatória, o autor deverá ser intimado para no prazo de 5 (cinco) dias emendar a petição inicial, pena de ser indeferida a tutela provisória e extinto o processo. Rigorosamente, o indeferimento da petição inicial, até porque se mostrará ele inepto para instaurar um processo pleno e definitivo. A diminuição do prazo de 15 (quinze) para 5 (cinco) dias representa um freio para o abuso do direito.

Observa-se, portanto, que a pretensão deduzida em caráter provisório tende e, mais, nasce com a vocação para transformar-se em um processo definitivo, voltado para a prolação de uma decisão também definitiva, que possa se qualificar pela coisa julgada material e estabilizar-se não apenas no seio do processo (endoprocessual) em que foi prolatada, mas estendendo-se para os possíveis futuros processos, vinculando não só as partes, mas especialmente os juízes, que não poderão decidir de forma contrária ao que ficou decidido no processo de origem.

O aditamento dar-se-á nos mesmos autos, dispensada a incidência de novas custas processuais, cumprindo ao autor desde logo, no pedido antecedente, indicar o valor da causa considerando já o pedido da tutela final, a demonstrar uma unidade procedimental entre o que se postula de forma antecedente e o que se pretende como decisão definitiva, ou seja, o pedido é formulado de forma antecedente, mas encontra sua sustentação na viabilidade de um processo definitivo.

Base no disposto no $§ 5^{\circ}$ do art. 303 (o autor indicará na petição inicial, ainda, que pretende valer-se do benefício previsto no caput deste artigo), a doutrina vem defendendo que o art. 303 oferece dois caminhos distintos: a) o autor pede a tutela antecipada em caráter antecedente, totalmente descompromissado com pretensão definitiva, desde logo, afirmando que apenas quer o provimento antecipatório; ou b) o autor requer a tutela antecipada e indica qual a lide principal e a tutela final - a qual está vinculada a pretensão antecipatória - que pretende no prazo legal declinar ${ }^{14}$.

A tanto se afirma pela interpretação dada ao art. 304 e à necessidade de o réu recorrer da decisão antecipatória, sob pena de se configurar a estabilidade do provimento antecipatório.

Defendemos interpretação distinta. Não está o autor, ao fazer uso da tutela antecedente e do procedimento estabelecido pelo art. 303, dispensado de preencher os demais requisitos desse dispositivo, quais sejam: (a) indicar o pedido de tutela final, (b) expor a lide principal e (c) indicar o direito (leia-se, subjetivo) que busca realizar.

Dizendo de outra forma, o autor conta no sistema processual com duas opções: ou, desde logo, ele promove o processo principal (porque está apto a fazê-lo) e requer tutela provisória satisfativa incidentalmente (tradição no processo civil), tudo em uma única petição, o que o afasta da vinculação aos arts. 303 ou 304, ou desdobra os seus pedidos, requerendo em caráter antecedente, em um 
primeiro momento, a tutela provisória satisfativa e, declinando os fundamentos do processo principal, se vale da dilação temporal para emendar a petição inicial na forma do $\S 1^{\circ}$, inciso I, do art. 303 , em um segundo momento, quando deduz a pretensão definitiva. Trata-se de um processo com vocação para processo definitivo, mas permite que preambularmente se limite a pretensão e a tutela a ser concedida (provisória) a uma fase preparatória, antecedente, mas que está ou deve estar apta a prosseguir com a segunda fase, qual seja a definitiva. Tanto é assim que o não atendimento à emenda da inicial leva à extinção do processo, conforme o $\S 2 \circ$ do predito dispositivo, sem qualquer exceção.

São inúmeros os dispositivos que sustentam essa orientação: a extinção do processo por falta de emenda $\left(\$ 2^{\circ}\right)$; a extinção do processo quando o juiz entender que não há elementos para a concessão de tutela antecipada e a emenda da petição inicial não for apresentada $\left(\S 6^{\circ}\right)$; o aditamento que ocorre nos mesmos autos e não se submete a novas custas processuais $\left(\S 3^{\circ}\right)$; o valor da causa a ser indicado na primeira petição que deverá levar em conta o pedido de tutela final.

Isso porque, no direito brasileiro, não há órgãos distintos para atender demandas de urgência e demandas ordinárias e definitivas: o juiz que detém competência para apreciar a tutela antecedente (seja satisfativa, seja cautelar) é o mesmo que decidirá a pretensão definitiva, ressalvadas competências recursais, mas que, no caso, se limitarão ao reexame do decidido.

De sorte que o disposto no $\S 5^{\circ}$ do art. 303 não tem a extensão pretendida, como se fosse dado ao autor promover, desde logo, um pedido de tutela provisória em caráter antecedente destinado a se esgotar nessa única pretensão e em um procedimento encurtado de suas fases cognitivas, embora nada impeça que essa consequência, eventualmente, seja alcançada.

Tem-se que o disposto no referido parágrafo agrega ao caput, e não cria uma segunda alternativa. Dizendo de outra forma, o autor poderá se valer, naquelas situações bem específicas em que a urgência é contemporânea com a proposição da ação, mas não dispõe ele de todos os elementos (postulatórios e probatórios) para, desde logo, implementar uma petição inicial com todos os requisitos que o processo definitivo exige, postular uma tutela provisória de natureza satisfativa antecedente, reservando-se a fundamentar o pedido definitivo no prazo que a lei ou o juiz lhe assinar. $O$ que se quer com a explicitação do $\S 5^{\circ}$ é que o autor defina, em nome inclusive do princípio da cooperação e do diálogo processual, se está promovendo a ação definitiva mediante cumulação de pedido antecipatório incidental, porque entende deter todos os elementos necessários para tanto, ou se está promovendo o pedido antecipatório de caráter antecedente, base na urgência e requerendo o benefício do tempo de aditamento. Trata-se do dever imposto ao autor, deixando claro, e sem sombras de dúvida, que sua demanda, com vocação para decisão definitiva, deve primeiro ser enfrentada pela via da provisoriedade. É o provisório com aptidão de tornar-se definitivo ${ }^{15}$. 
Com outras palavras, não há, no capítulo dos arts. 303 e 304, duas postulações de urgência, (a) uma provisória voltada a ser definitiva e (b) outra apenas provisória, sem qualquer pretensão de definitividade. Ou o autor se vale do procedimento do art. 303, com todos os desdobramentos que os respectivos parágrafos dispõem, ou terá o seu pedido indeferido e o processo extinto: § 2० do art. 303 (não realizado o aditamento a que se refere o inciso I do $\S 1^{\circ}$ deste artigo, o processo será extinto sem resolução do mérito). $\mathrm{O} \S 5^{\circ}$ não tem, por si só, o poder de criar uma (outra) opção procedimental ao autor que não a do caput, agregado dos demais parágrafos. A pretensão inicial provisória, mas culmina por tornar-se definitiva.

Quanto ao agir do réu, aí sim, o Código prevê uma opção distinta, a saber.

5.3 A extinção do processo por opção do réu na tutela antecipada requerida em caráter antecedente: princípio da utilidade do processo

Em complementação ao procedimento da tutela antecipada requerida em caráter antecedente, apto a transformar-se em processo definitivo, o Código traz em seu art. 304, § 1\%, hipótese de extinção do processo provocada pelo réu, ao não oferecer resistência ao pedido do autor via interposição de recurso.

Retomando, em parte, o iter previsto no caput do art. 303, proposta a pretensão em caráter antecedente, uma vez concedida a antecipação de tutela, o réu dela tomará conhecimento, presumidamente desde logo, por ocasião de seu cumprimento (que se dará, de regra, por mandado judicial). Em tomando ciência, independentemente de ser regularmente citado (citação só ocorrerá depois de emendada a inicial pelo autor), abre-se prazo para que o réu ou sujeite-se ao comando antecipatório cumprindo-o integralmente e omitindo-se (quem cala consente), ou, mostrando oposição à pretensão do autor e instaurando, desde logo, a controvérsia, recorra via agravo de instrumento (art. 1.015, inciso I, CPC/2015).

Ao recorrer, já está se posicionando o réu: não concorda com o autor e pretende se valer do processo definitivo, no momento oportuno, quando citado, abrindo-se para uma possível autocomposição ou preparando-se para contestar a ação, controvertendo o direito subjetivo posto em causa.

E a forma de o réu manifestar-se é por meio do recurso de Agravo de Instrumento. Seja porque o dispositivo em comento assim determina ao se utilizar da expressão "respectivo recurso", seja porque o art. 1.015, inciso I, explicita que contra as decisões proferidas em sede de tutela provisória o recurso cabível é o agravo de instrumento, aplicando-se aqui o princípio da taxatividade recursal.

Mas também pode acontecer de o réu se conformar desde logo, com a medida antecipatória, não pretendendo levar adiante a discussão judicial. Fredie Didier Jr., Paula Sarno Fraga e Rafael Alexandria de Oliveira trazem interessante e apropriado exemplo que se adapta à hipótese arregimentada, mostrando a utilidade de sua previsão, representada pela ausência de interposição de recurso e consequente extinção do processo 
Imagine um caso em que um estudante, que ainda não havia concluído o ensino médio, tenha sido aprovado no vestibular para um curso superior. A instituição de ensino, seguindo determinação do Ministério da Educação, não realizou a matrícula. $O$ estudante vai a juízo e obtém uma tutela satisfativa liminar, ordenando a matrícula. Para a instituição de ensino, pode ser que não haja qualquer interesse em contestar a medida - ela somente não matricularia o aluno, porque o Ministério da Educação proibia ${ }^{16}$.

O desinteresse da parte ré, em situações tais, libera o demandado a tão somente cumprir a ordem judicial ou a ela não objetar qualquer resistência, com o que o processo se extingue e não há qualquer outra consequência em relação às partes, inclusive de natureza sucumbencial, até porque não houve ainda a angularização da relação processual, já que o réu sequer foi citado. Sua ciência se dá exclusivamente ao comando judicial da tutela antecipada e à respectiva execução e/ou cumprimento. Por óbvio que nesses casos, com a extinção do processo, o procedimento previsto no art. 303 (prazo para o autor emendar a inicial e expedição de mandado de citação para audiência de conciliação ou mediação) fica prejudicado, assim como fica prejudicado tanto o processo como a medida antecipatória caso o autor não emende a petição nos termos do art. 303, § 20, extinguindo-se o feito sem exame do mérito.

Em tese, pelo menos, e na abstração do texto legislativo, primeiro - em termos cronológicos - deverá ocorrer a tomada de posição pelo réu: concorda, anui e se esgota todo o litígio, ou recorre, assumindo sua condição de litigante e futuro contestante. Basta isso para que o processo seja extinto ou prossiga, e, em prosseguindo, o autor deve dar andamento ao processo definitivo, emendando a petição inicial.

Outros exemplos, inclusive na seara de direito de família, poderiam ser deduzidos, mas o fato é que a extinção do processo sem maiores consequências passa a ser um estímulo para aquele que, não tendo interesse processual de controverter a relação jurídica ou mesmo sabedor de que não é portador de um bom direito, limite-se a cumprir a providência judicial não opondo nenhuma resistência. Nada mais célere e efetivo que o réu se render à pretensão do autor, em um processo que não lhe causa nenhum prejuízo, restando alcançado o fim último da prestação jurisdicional e da pacificação social nas relações jurídicas. É a realização máxima da utilidade do processo, princípio que rege a função da prestação judicial.

Diferentemente do procedimento da tutela cautelar requerida em caráter antecedente, em que cumpre ao autor, indistintamente promover o regular processamento do feito uma vez concedida a tutela cautelar antecedente (tenha ou não sido submetida a recurso pelo demandado), sob pena de sua cassação (art. 309, incisos I e II), na tutela satisfativa antecedente, independentemente das providências entregues ao autor, que dizem não com a antecipação, mas sim com o processo definitivo, o réu tem a opção de (a) seguir com o processo definitivo, 
recorrendo da decisão antecipatória e aguardando o momento certo para deduzir todas as suas defesas ou, (b) reconhecendo o direito do autor, render-se à tutela antecipada, sem qualquer objeção, deixando de recorrer e, portanto, levando à extinção do processo.

\subsection{A tutela cautelar antecedente e a tutela cautelar incidente}

Adentra-se, agora, na tutela de urgência cautelar requerida em caráter antecedente, que o processo brasileiro desde o Código de 1973 sempre contemplou e que o novo CPC prevê nos arts. 305 a 310.

$\mathrm{O}$ art. 305 estabelece que a petição inicial que visa à prestação cautelar em caráter antecedente - portanto, pressupondo instauração de um processo definitivo em momento oportuno - exige os mesmos requisitos para a cautela antecedente do Código de 1973, quais sejam, indicação da lide e de seus fundamentos, com a exposição sumária do direito (leia-se, direito subjetivo) que se pretende assegurar frente ao perigo de dano ou risco ao resultado útil do processo. Pode-se afirmar, com Jaqueline Mielke Silva, que a opção do legislador foi, em uma concepção de processo constitucional, pela asseguração de direitos subjetivos, abdicando de vez da ideia de que a tutela cautelar é instrumento do instrumento ${ }^{17}$. O que está em jogo são os direitos subjetivos dos litigantes, irrelevante se a tutela é satisfativa ou de natureza cautelar.

O procedimento, por sua vez, não apresenta grandes novidades, sendo a pretensão cautelar recebida pelo juiz, sem prejuízo da aplicação da fungibilidade (art. 305, parágrafo único), adequando a pretensão ao art. 303 se entender que se trate de pretensão antecipatória satisfativa, será o réu citado para em 5 (cinco) dias contestar o pedido e indicar as provas que pretende produzir. No ponto, sequer a padronização dos prazos, marco do novo Código, foi recepcionada, mantendo-se para a pretensão cautelar a defesa no prazo reduzido de um quinquídio. Por óbvio, que nada impede a interposição do recurso de agravo de instrumento contra a decisão que acolhe ou rejeita a tutela cautelar, na forma do art. 1.015, inciso I, do CPC/2015, porque igualmente se trata de decisão que versa sobre tutela provisória.

Em havendo revelia - com a assunção dos fatos articulados pelo autor como verdadeiros - ou contestando o réu a pretensão, segue-se, no primeiro caso, a prolação da sentença; no segundo, a adoção do procedimento comum, com investigação probatória e posterior sentença.

A inovação procedimental vem no art. 308, que reúne nos mesmos autos o pedido cautelar e o pedido principal, a ser formulado pelo autor no prazo de 30 (trinta) dias, seguindo-se - o que também é um vetor do novo Código - a tentativa de autocomposição, via audiência de conciliação ou de mediação.

A principal distinção, sob o aspecto procedimental, entre a tutela antecipada e a tutela cautelar, requeridas ambas em caráter antecedente, está que, no 
primeiro caso, o protagonista maior do prosseguimento feito é o réu, recorrendo ou deixando de recorrer, enquanto que, na segunda hipótese, cumpre ao autor o agir para que a demanda não seja extinta com a consequente desconstituição da tutela provisória concedida.

No $\S 1^{\circ}$ do art. 308 vem a possibilidade de a tutela cautelar ser requerida conjuntamente com o pedido principal, situação já defendida quanto à tutela satisfativa incidental no presente trabalho e que, mesmo sob a vigência do Código de 1973, já se acolhia.

$\mathrm{O}$ aditamento da causa de pedir no caso da tutela cautelar antecedente, a exemplo da tutela satisfativa antecedente, é permitido, ainda que, nesse caso, o prazo mínimo é de 15 (quinze) dias e, naquele, o prazo máximo é de 30 (trinta) dias, acontecendo quando da proposição do pedido principal e definitivo.

Em ambas as hipóteses, concedida a tutela provisória, o réu será citado para audiência de conciliação ou mediação, a partir da qual se abrirá o prazo, se for o caso, de contestação, na forma do art. 335 do CPC/2015.

De qualquer sorte, o Código prevê a propositura de tutela cautelar antecedente, mas não veda a conjugação de tutela cautelar e pretensão definitiva em uma única peça e em um único momento processual, limitando-se a estabelecer critérios específicos para que haja a conversão do pedido cautelar em pedido definitivo. Técnica procedimental que se aproxima da tutela antecipada satisfativa incidental, como alhures visto.

\section{ESTABILIZAÇÃO DA TUTELA PROVISÓRIA ANTECEDENTE}

Em sede de tutela provisória e da jurisdição de urgência, é a estabilização da decisão que a concede o passo mais significativo a caminho de um novo paradigma de processo e de prestação jurisdicional.

Nítida a influência do direito francês e da figura do réferé, a tutela provisória está intimamente comprometida com a urgência e a sumariedade, afirmando Jânia Maria Lopes Saldanha

A figura do réferé, desde logo, envolve questão interessante: a justiça não teria por missão proferir decisões definitivas ao processo quando provocada? Mas não é um fato que os juízes ordenam medidas provisórias para evitar que o cidadão sofra os prejuízos da espera?

Em princípio, parece fácil afirmar que, ao conceder uma medida provisória, como nos provimentos antecipatórios da tutela, ou ao conceder uma medida temporária como ocorre nas ações cautelares, o juiz não analisa o mérito do litígio em oposição às decisões que "dizem o direito" e, por ter sua decisão efeito limitado no tempo, não produz coisa julgada. 
Mas é justamente esta uma das principais características da jurisdiction des réferés. Tal provisoriedade repousa menos em sua limitação no tempo do que na possibilidade de que a ordem réferé seja revisada por uma decisão contrária de competência de outro órgão jurisdicional de composição colegiada que, teoricamente, não está ligado ao juízo anteriormente realizado. A experiência francesa mostra que essa segunda provocação pouco ocorre. Essa abstenção da parte interessada gerou uma autoridade de fato do réferé sobre o julgamento de mérito e evidencia o apreço a esse tipo de jurisdição ${ }^{18}$.

O novo Código traz em seu artigo 304 uma proposta de estabilização da decisão provisória (não da lide), que encontra, como visto alhures, alguma afinidade com o réferé francês, mas que também se aproxima da técnica de monitorização da demanda, sem embargo de guardar peculiaridades próprias, distinguindo-se daquelas.

Nos procedimentos monitórios ${ }^{19}$, parte-se de uma forte verossimilhança dos fatos alegados pelo autor (de regra, prova documental), dispensado o requisito de urgência, ao efeito de autorizar uma ordem de pagamento ou cumprimento (monir), que tanto pode, em tese, se estender à obrigação de pagar ou entregar coisa, como às obrigações de fazer ou não fazer, ficando as opções de prosseguimento a critério do réu: (a) cumprindo a ordem, extingue-se o processo; (b) ofertando oposição, ordinariza-se a demanda, estabelecendo-se a inversão do contraditório; ou (c) omitindo-se, a ordem emitida originalmente em caráter provisório torna-se definitiva.

Nos casos de antecipações satisfativas antecedentes, qualquer direito e não apenas o direito de crédito está por elas acobertado; exige-se um mínimo de verossimilhança quanto aos fatos alegados, que pode inclusive ser por meio de prova testemunhal em audiência preliminar (art. 300, § 20); e a urgência é condição sine qua non para a concessão da tutela postulada.

De qualquer sorte, a estabilização da decisão provisória decorre, a exemplo dos procedimentos monitórios, da conduta do réu. Não é o autor, mas o réu que decide se vai ou não controverter a pretensão deduzida pelo autor. Assim, tomando ciência da tutela concedida, o réu pode recorrer, provocando junto à instância recursal o reexame da decisão interlocutória, sem prejuízo de sua defesa plena e ampla no processo que se instaurará na forma do art. 303, ganhando a controvérsia foro de ordinariedade e de definitividade.

Mas pode também apenas render-se ao pedido do autor e ao comando judicial, o que implicará a extinção do processo e a estabilização da decisão provisória, o que não significa que ela se torne definitiva, enquanto julgamento do conflito.

Nesse fio, os parágrafos 2o, 3o e $4^{\circ}$ do art. 304, que permitem que qualquer das partes - autor ou réu - poderá demandar a parte adversa com o intuito de rever (inclusive para ampliar os seus efeitos, no interesse do autor), reformar (para 
mais ou para menos, conforme interesse do autor ou do réu) ou para invalidar a decisão de mérito concedida em caráter sumário e provisório (no interesse do réu). Para tanto, os autos ficarão à disposição da parte que vir a demandar, sendo desarquivados com o fito de instruir a petição inicial. Nessa provocação ou segunda demanda, a jurisdição a ser exercida será plenária e definitiva.

Peculiar a natureza do prazo estabelecido no $\S 5^{\circ}$ do art. 304: O direito de rever, reformar ou invalidar a tutela antecipada, previsto no $\S 2^{\circ}$ deste artigo, extingue-se após 2 (dois) anos, contados da ciência da decisão que extinguiu o processo, nos termos do $\S 1$.

Não há que se falar em coisa julgada material porque, decorrido o prazo binário estabelecido pela lei processual sem que as partes tenham provocado a ação do $\S 22^{\circ}$, decisão que se submete a indiscutibilidade e imutabilidade que definem a coisa julgada são as decisões definitivas, jamais as decisões provisórias. Estas não contam com os elementos necessários para a sua eternização.

Por outro lado, não há que se falar em decadência ou prescrição, porque institutos de natureza de direito material, regrados que são pelas leis de direito material.

Remanesce, porém, o comando impositivo da lei processual: a ação para discutir o direito subjetivo que foi atendido, em caráter sumário e por decisão provisória, se esgota no prazo de 2 (dois) anos.

Trata-se, no nosso sentir, de hipótese de perempção, o que exige, porém, aprofundamento que o presente texto não autoriza ${ }^{20}$.

\section{TUTELA DE URGÊNCIA E PROCESSO COLETIVO: DIÁlOGO DAS FONTES}

Considerando que o texto legislativo matriz, no direito brasileiro, para reger o processo coletivo é a Ação Civil Pública regulada pela Lei n. 7.347, de 1985, importa aqui analisar a adequação desse estatuto e sua aderência, no que diz com as tutelas de urgência (antecipatórias e cautelares) com o novo Código de Processo Civil, que indiscutivelmente à ação civil pública deverá incidir subsidiariamente.

Nada impede, outrossim, que de lege ferenda algumas ponderações sejam deduzidas sobre eventual proposta de um Código de Processo Coletivo.

No particular, a Lei da Ação Civil Pública limita-se a tratar da tutela de urgência em seu art. 4\%:

Poderá ser ajuizada ação cautelar para os fins desta Lei, objetivando, inclusive, evitar o dano ao meio ambiente, ao consumidor, à ordem urbanística ou aos bens e direitos de valor artístico, estético, histórico, turístico e paisagístico.

A redação do texto, cediço, remonta ao ano de 1985, muito antes de o Código de Processo Civil então vigente (1973) trabalhar, por força das sucessivas 
reformas que os anos noventa e o primeiro decêndio de dois mil produziram, com as tutelas antecipatórias genéricas, só introduzidas no processo civil por força de reformas a partir de 1994. De qualquer sorte, o art. 12 da Lei da Ação Civil Pública dispõe expressamente: Poderá o juiz conceder mandado liminar, com ou sem justificação prévia, em decisão sujeita a agravo.

Seja por força das reformas no processo civil, seja pela evolução doutrinária e jurisprudencial em relação às tutelas de urgência, os provimentos antecipatórios satisfativos foram assimilados pela ação civil pública, independentemente da rigidez do conteúdo do art. $4^{\circ}$, que deve ser compreendido em harmonia com o art. 12 e no contexto jurídico das tutelas de urgência, que tanto podem ser de natureza cautelar como satisfativa.

Com o advento do novo Código de Processo Civil, não há mais que se falar, no direito brasileiro, em ação cautelar. Trata-se de figura processual definitivamente revogada. Cumpre, pois, ao intérprete promover o diálogo das fontes, entre o Código de Processo, que regulamenta de forma sistêmica o instituto da tutela provisória, e a lei de regência do processo coletivo, no caso, a Lei da Ação Civil Pública.

De sorte que, em sede de ação civil pública, poderá o autor, devidamente legitimado a promovê-la, requerer, em caráter incidental, ou a antecipação de tutela de efeito(s) da sentença (natureza satisfativa), ou, ainda, conforme a pretensão deduzida, cumular tutela cautelar liminar, considerando os requisitos previstos no art. 300 do estatuto processual, sujeitando-se às exigências ali expostas: a) alegar e convencer o juízo dos requisitos da probabilidade do direito e do perigo de dano ou risco ao resultado útil do processo; b) submeter-se a eventual exigência de caução ou provocar sua dispensa, por força da qualificação do rol de legitimados do art. $5^{\circ}$, da Lei n. 7.347/85, legalmente dispensados de pagamento prévio de custas ou preparo; c) ofertar prova que autorize a concessão liminar da tutela provisória ou submeter-se à audiência de justificação prévia; d) não declinar em sede de urgência pretensões qualificadas pela irreversibilidade.

Poderá, ainda, antecipadamente, deduzir pretensão de natureza cautelar antecedente, observando as regras do art. 305 e seguintes, entre as quais se destaca a necessidade de, em tempo hábil, promover o processo principal, nos termos do art. 308 do CPC de 2015.

De difícil aderência, porém, será a promoção da tutela antecipada requerida em caráter antecedente, conforme arts. 303 e 304 do novo Código, cuja previsão é incompatível com a ação civil pública e os bens da vida que objetiva tutelar. No mesmo caminho, a pretensão deduzida, que diz com os direitos ou interesses difusos, transindividuais, metaindividuais, não convive com a ideia de estabilidade proposta pela lei processual, carecendo da definitividade que só a sentença de mérito pode conferir, sentença essa apta a produzir a indiscutibilidade e imutabilidade da coisa julgada material, que a estabilidade da tutela antecipada concedida em caráter antecedente não logra alcançar. 
A tutela de urgência prevista no art. 303 e submetida às regras do art. 304 do Código de 2015 tem vocação para demandas outras que não se revestem do grau de complexidade que só o processo comum e a jurisdição definitiva estão aptos a solver. Em princípio, atendem situações concretas em que onde o conflito é tênue, superficial, pouco consistente e poderá, pela simples omissão do réu em recorrer da decisão que concedeu a tutela antecipada em caráter antecedente resolver-se nesse único ato judicial. São situações, como dito alhures, que se resolvem em uma decisão, abdicando de um julgamento.

No processo coletivo, ao contrário, todo o conflito nele vertido ganha feição de extrema complexidade, envolvendo uma cidadania coletiva, com repercussão erga omnes, que não pode ser reduzido a uma decisão sumária e de natureza provisória, que só alcança a estabilidade pela omissão do réu em ofertar resistência.

Por outro lado, regra ínsita à tutela de urgência, é a indenização pelos danos ou pelos prejuízos que sua efetivação pode causar à parte adversa, prevendo o Código de 2015 uma responsabilidade objetiva nas seguintes hipóteses: a) sentença desfavorável ao autor; b) negligência do autor em fornecer os meios necessários para a citação do requerido quando obtida a tutela cautelar antecedente, no prazo de 5 ( cinco) dias; c) cessação da eficácia da medida em qualquer hipótese legal; d) reconhecimento, pelo juiz, da decadência ou da prescrição da pretensão do autor.

Em sede de ação civil pública - o que pertine ao processo coletivo - o art. 18 da Lei n. 7.347/85 prevê que não haverá adiantamento de custas, emolumentos, honorários periciais e quaisquer outras despesas, nem condenação da parte autora a honorários advocatícios ou quaisquer outras despesas, salvo comprovada má-fé. Ora, a regra goza de fundamento principiológico: acesso à justiça o mais amplo e irrestrito possível pela via do processo coletivo, com vistas aos interesses e aos direitos da cidadania coletiva. Apenas a litigância de má-fé autoriza tais condenações, o que deve ser estendido à ideia de qualquer outra reparação.

Não se está defendendo a ausência de reparação por eventuais prejuízos, mas exigindo-se que esta só seja reconhecida e aplicada pela via da responsabilidade subjetiva, na medida em que se está frente a um processo coletivo. Trata-se de limitação da maior relevância sob pena de se intimidar a parte autora, representante da coletividade, a renunciar ao pedido de tutela de urgência, no mais das vezes faz necessária nos conflitos coletivos, frente aos riscos de uma improcedência, cuja probabilidade, em maior ou menor grau, sempre se faz presente.

\section{CONSIDERACุÕES FINAIS}

O processo civil, desimportanto se o conflito é individual, coletivo ou repetitivo, está em crise, e isso significa sua releitura, o desvelamento de suas instituições e estruturas, sob o manto da constitucionalidade e do rol de garantias fundamentais da pessoa humana. 
Por outro lado, cada vez mais necessária a previsão de uma jurisdição de urgência, ainda que de caráter provisório.

As novidades introduzidas pelo Código de 2015, no particular, não estão imunes à crítica e a possíveis insuficiências frente às múltiplas e cada vez mais variadas exigibilidades fundadas no direito material e na significativa complexidade das relações jurídicas de uma sociedade plúrima, de alta rotatividade, em que o tempo não mais se mede pelo relógio tradicional.

Mas ignorar o problema - necessidade de o ordenamento jurídico contar com tutelas apropriadas no conteúdo e no tempo às pretensões deduzidas - não é a solução. A divergência e a convergência de ideias sobre o texto normativo é altamente produtivo, contribuindo para o aperfeiçoamento e a consolidação de propostas que contêm em si - e esta é a leitura que defendemos - a finalidade última de concretizar um processo civil democrático, efetivo e tempestivo, aí se enquadrando as tutelas provisórias como contraponto às tutelas definitivas, estas com vocação para a indiscutibilidade e imutabilidade do julgamento, privilegiando a paz social e a segurança jurídica, aquelas com vocação para resolver de pronto o caso concreto repondo as partes ao statu quo no mínimo razoável.

E se tais tutelas são importantes no processo individual, mais ainda quando se está a tratar do processo coletivo, em que os interesses e direitos tutelados integram a uma coletividade que está à mercê do Poder Judiciário para ver seus direitos fundamentais serem assegurados e concretizados, último espaço democrático de concretização da ordem jurídica. O diálogo das fontes - código de processo e lei do processo coletivo -, aproximando o que há de comum ou de aderência entre tais regulamentos próprios e repudiando o que não é compatível, é o caminho proposto.

\section{REFERÊNCIAS}

CALAMANDREI, Piero. Nocion unitaria de jurisdiccion, in: GREIF, Jaime. El processo: vision y desafios, Fundacion de Cultura Universitaria: Montevideo, Uruguay, 1993.

DIDIER Jr., Fredie. In: DIDIER Jr, Fredie; BRAGA, Paulo Sarno; OLIVEIRA, Rafael Alexandra (Orgs.). Curso de direito processual civil: teoria da prova, direito probatório, ações probatórias, decisão, precedente, coisa julgada e antecipação dos efeitos de tutela. 10. ed. Salvador: Ed. Jus Podivm, 2015, v. 2.

MACEDO, Elaine Harzheim. Do procedimento monitório. 2a tiragem, São Paulo: Ed. Revista dos Tribunais, 1999.

. De Salomão à Escolha de Sofia: proposta de legitimação da decisão judicial à luz da Constituição de 1988, in MOLINARO, Carlos Alberto; MILHORANZA, Mariângela Guerreiro; PORTO, Sérgio Gilberto (Coords.). Constituição, Jurisdição e Processo: estudos em homenagem aos 55 anos da Revista Jurídica. Sapucaia do Sul: Notadez, 2007, pp. 259-296. 
; MACEDO, Fernanda dos Santos. O Direito Processual Civil e a Pós-modernidade. Trabalho apresentado e defendido junto ao XX Encontro Nacional do CONPEDI, Belo Horizonte, 2011, anais em vias de publicação. Disponível em: <http:www.conpedi.org.br/eventos/>. Acesso em: 05 jul. 2011.

; VIAFORE, Daniele. A decisão monocrática e a numerosidade no processo civil brasileiro. Porto Alegre: Livraria do Advogado Editora, 2015.

. Prestação jurisdicional em sede de tutela antecedente: procedimento, estabilização da decisão e decurso do prazo de 2 (dois) anos: um novo caso de perempção? No prelo.

MARINONI, Luiz Guilherme. Técnica processual e tutela dos direitos. 4. ed. São Paulo: Revista dos Tribunais, 2013.

. In: MARINONI, Luiz Guilherme; ARENHART, Sérgio Cruz; MITIDIERO, Daniel (Orgs.). Novo código de processo civil comentado. São Paulo: Editora Revista dos Tribunais, 2015.

SALDANHA, Jânia Maria Lopes. Substancialização e efetividade do direito processual civil: a sumariedade material da jurisdição: proposta de estabilização da tutela antecipada em relação ao Projeto de Novo CPC. Curitiba: Juruá, 2011.

REALE, Miguel. Conceito de cultura: seus temas fundamentais. (In) Paradigmas da cultura contemporânea. 2. ed., São Paulo: Saraiva, 1999.

SILVA, Jaqueline Mielke. A tutela provisória no novo Código de Processo Civil. Porto Alegre: Verbo Jurídico, 2015.

SILVA, Ovídio A. Baptista da. Curso de Processo Civil. Porto Alegre: Sergio Antonio Fabris Editor, 1993, v. 3.

Processo e ideologia: o paradigma racionalista. Rio de Janeiro: Editora Forense, 2004.

. Epistemologia das ciências culturais. Porto Alegre: Verbo Jurídico, 2009.

1 Para aprofundamento do tema, remete-se o leitor para MACEDO, Elaine Harzheim; VIAFORE, Daniele. A decisão monocrática e a numerosidade no processo civil brasileiro. Porto Alegre: Livraria do Advogado Editora, 2015.

2 Para uma melhor abordagem do tema da discussão sobre o processo civil na pós-modernidade, remete-se o leitor para MACEDO, Elaine Harzheim e MACEDO, Fernanda dos Santos. O Direito Processual Civil e a Pós-modernidade. Trabalho apresentado e defendido junto ao XX Encontro Nacional do CONPEDI, Belo Horizonte, 2011, anais em vias de publicação. Disponível em: 〈http:www.conpedi.org.br/eventos/〉. Acesso em: 5 jul. 2011.

3 SILVA, Ovídio A. Baptista da. Epistemologia das ciências culturais. Porto Alegre: Verbo Jurídico, 2009, p. 19.

4 REALE, Miguel. Conceito de cultura: seus temas fundamentais. (In) Paradigmas da cultura contemporânea. 2. ed., São Paulo: Saraiva, 1999, p. 1.

5 Dentre tantos, Ovídio A. Baptista da Silva (Processo e ideologia: o paradigma racionalista, Rio de Janeiro: Editora Forense, 2004) e Luiz Guilherme Marinoni (Técnica processual e tutela dos direitos, 4. ed. São Paulo: Revista dos Tribunais, 2013). 
6 Tramitam no Congresso Nacional projetos de lei com vistas à introdução de um Código de Processo Coletivo e/ou reforma da Lei da Ação Civil Pública, sem embargo de outras propostas que estão sendo gestadas na comunidade jurídica. Nesse sentido, o PL 5.139/2009 que, segundo site da Câmara dos Deputados, teve sua última movimentação em 2010: <http://www.camara.gov.br/proposicoesWeb/fichadetramitacao?idPro posicao $=432485>$, acesso em: $12 \mathrm{dez}$. 2015. Por outro lado, movimentos da comunidade jurídica trabalham paralelamente no tema, a exemplo do Núcleo de Estudos sobre Processos Coletivos da Escola da Ajuris, que construiu uma proposta de anteprojeto de lei de processo coletivo: <http://www.escoladaajuris.org. br/esm/imagens/Processo\%20Coletivo\%20Minuta\%203\%20Anteprojeto.pdf>.acesso em 12 dez. 2015.

7 Influências essas insistentemente denunciadas por Ovídio A. Baptista da Silva, ao longo de sua obra e reiteradas in Epistemologia das ciências culturais, Porto Alegre: Verbo Jurídico, 2009, destacando-se à p. 55 a seguinte lição: "O resultado inevitável para o controle de uma sociedade de indivíduos autônomos, capazes de construirem seus próprios destinos, livres dos antigos vínculos comunitários medievais, foi a progressiva jurisdicização do mundo, como instrumento que se imaginou capaz de substituir os antigos vínculos comunitários." Concluindo: "Era, ainda, a segurança a presidir os vínculos comunitários pela coerção jurídica".

8 CALAMANDREI, Piero. Nocion unitaria de jurisdiccion, in: GREIF, Jaime. El processo: vision y desafios, Fundacion de Cultura Universitaria: Montevideo, Uruguay, 1993, p. 35

9 SALDANHA, Jânia Maria Lopes. Substancialização e efetividade do direito processual civil - a sumariedade material da jurisdição: proposta de estabilização da tutela antecipada em relação ao Projeto de Novo CPC. Curitiba: Juruá, 2011, p. 189.

10 MACEDO, Elaine Harzheim. De Salomão à Escolha de Sofia: proposta de legitimação da decisão judicial à luz da Constituição de 1988, in MOLINARO, Carlos Alberto; MILHORANZA, Mariângela Guerreiro; PORTO, Sérgio Gilberto (Coords.). Constituição, Jurisdição e Processo: estudos em homenagem aos 55 anos da Revista Jurídica. Sapucaia do Sul: Notadez, 2007, p. 259-296.

11 SILVA, Ovídio A. Baptista da. Curso de Processo Civil. Porto Alegre: Sergio Antonio Fabris Editor, 1993, v. 3, p. 25.

12 Nas ações possessórias, conforme art. 562 (estando a petição inicial devidamente instruída, o juiz deferirá, sem ouvir o réu, a expedição do mandado liminar de manutenção ou de reintegração, caso contrário, determinará que o autor justifique previamente o alegado, citando-se o réu para comparecer à audiência que for designada), a antecipação de tutela reclama requisitos próprios.

13 Art. 334. Se a petição inicial preencher os requisitos essenciais e não for o caso de improcedência liminar do pedido, o juiz designará audiência de conciliação ou de mediação com antecedência mínima de 30 (trinta) dias, devendo ser citado o réu com pelo menos 20 (vinte) dias de antecedência.

14 Nesse sentido a doutrina de DIDIER Jr., Fredie et all. Curso de direito processual civil: teoria da prova, direito probatório, ações probatórias, decisão, precedente, coisa julgada e antecipação dos efeitos de tutela. 10. ed. Salvador: Ed. Jus Podivm, 2015, v. 2, p. 606 e de SILVA, Jaqueline Mielke. A tutela provisória no novo Código de Processo Civil. Porto Alegre: Verbo Jurídico, 2015.

15 MACEDO, Elaine Harzheim. Prestação jurisdicional em sede de tutela antecedente: procedimento, estabilização da decisão e decurso do prazo de 2 (dois) anos: um novo caso de perempção? No prelo.

16 FREDIE JR. Didier et all, ob. cit., p. 605.

17 SILVA, Jaqueline Mielke. A tutela provisória no novo Código de Processo Civil. Porto Alegre: Verbo Jurídico, 2015.

18 SALDANHA, op. cit., p. 376-377.

19 Para aprofundamento do tema, remete-se o leitor para MACEDO, Elaine Harzheim. Do procedimento monitório. 2a tiragem. São Paulo: Ed. Revista dos Tribunais, 1999.

20 Remete-se o leitor para o artigo antes referido: "Prestação jurisdicional em sede de tutela antecedente: procedimento, estabilização da decisão e decurso do prazo de 2 (dois) anos: um novo caso de perempção?", no prelo. 


\title{
PROVISONAL INJUNCTION IN COLLECTIVE SUIT: A DIALOGUE BETWEEN THE NEW CODE OF PROCEDURAL LAW AND THE STATUTE OF PUBLIC CIVIL SUIT
}

\begin{abstract}
The class action is a democratic space of conflict composition that must connect with different injunctions, which aims a plural or collective citizenship, owner of collective rights. As happens in the individual procedure, the time the procedure takes and its default can be responsible for the ineffectiveness of the injunction in the class action. This situation justifies the application of the provisional injunction, issued in the Code of Procedural Law of 2015, when applicable to class actions, in a dialogue with the Class Action law. Both, the incidental provisional injunction and the pre-emptive injunction are related to the procedure issued by the law $7.347 / 85$. The same situation is not true in the case of antecedent provisional injunction regarding the assets of life, because it demands a definitive decision. Also, the prevision of objective liability, within the provisional injunction, to repair the tort caused to the defendant are impertinent to the class action, and this situation must happen only when there is subjective responsibility because the complainant acts in bad faith .
\end{abstract}

Keywords: Class action. Provisional injunction. Preemptive injunction. New CPC.

Submetido: 21 dez. 2015

Aprovado: 15 jan. 2016 